\title{
MIGRASI INTERNASIONAL PEREMPUAN DESA DAN PEMANFAATAN REMITAN DI DESA PUSAKAJAYA, KECAMATAN PUSAKAJAYA, KABUPATEN SUBANG, PROVINSI JAWA BARAT
}

\author{
Women International Migration and Remittances in Pusakajaya Village \\ Tuty Irawaty ${ }^{*}$ ) dan Ekawati Sri Wahyuni \\ Departemen Sains Komunikasi dan Pengembangan Masyarakat, Fakultas Ekologi Manusia, IPB \\ *) Email : irawatytuty@yahoo.com
}

Diterima 11 November 2011 / Disetujui 23 November 2011

\begin{abstract}
International migration is happened due to the growth of population which not balance with the growth of job opportunities. Village women who not have many skills concider that international migration is a golden opportunity to increase economy of their family. This problem is very complex but it is interesting to be studied. The aim of the research is to identify the factors which caused women in village went abroad to working and utilization of remittances in household migrant. This study is conducted by a survey method that is an explanation and descriptive research. The area studies was Pusakajaya village, Subang, West Java, Indonesia. Based on the research findings, the availability of jobs in destination areas and the limited agricultural land in the area of origin became major factors for women in village to work abroad. Utilization of remittances in the villages of Pusakajaya is allocated to met the needs of consumption, production, investments in education and economic, while the allocation of social investment is not found. Utilization of remittances by migrant families in the village of Pusakajaya form a common pattern in fulfilling the needs of consumption and investment education.
\end{abstract}

Keywords: international migration, migrant women workers, remittances.

\begin{abstract}
ABSTRAK
Migrasi internasional terjadi karena pertumbuhan penduduk yang tidak diimbangi dengan pertumbuhan kesempatan kerja. Bagi perempuan desa yang tidak memiliki banyak keterampilan, migrasi internasional adalah kesempatan emas untuk meningkatkan ekonomi keluarga mereka. Masalah ini sangat kompleks tapi menarik untuk dikaji. Tujuan dari penelitian ini adalah untuk mengidentifikasi faktor-faktor yang menyebabkan perempuan di desa pergi ke luar negeri untuk bekerja dan pemanfaatan remitansi dalam rumah tangga migran. Penelitian ini dilakukan dengan metode survei yang merupakan penjelasan dan penelitian deskriptif. Penelitian daerah adalah Pusakajaya Desa, Subang, Jawa Barat, Indonesia. Berdasarkan temuan penelitian, ketersediaan lapangan kerja di daerah tujuan dan lahan pertanian terbatas di daerah asal menjadi faktor utama bagi perempuan di desa untuk bekerja di luar negeri. Pemanfaatan remitan di Desa Pusakajaya dialokasikan untuk memenuhi kebutuhan konsumsi, produksi, investasi di bidang pendidikan dan ekonomi, sedangkan alokasi investasi sosial tidak ditemukan. Pemanfaatan pengiriman uang oleh keluarga migran di Desa Pusakajaya membentuk pola umum dalam memenuhi kebutuhan konsumsi dan investasi pendidikan.
\end{abstract}

Kata kunci: migrasi internasional, para pekerja migran perempuan, pengiriman uang.

\section{PENDAHULUAN}

\section{Latar Belakang}

Keterlibatan perempuan dalam kegiatan ekonomi merupakan fenomena penting pada era globalisasi. Perempuan Indonesia perdesaan terutama kalangan menengah ke bawah hampir seluruhnya terlibat dalam kegiatan ekonomi. Mereka berupaya memperbaiki ekonomi keluarga hingga meninggalkan desa dan mencari alternatif pekerjaan. Melihat peran perempuan dalam kajian-kajian strategi ekonomi rumah tangga (livelihood strategies), nampak jelas bagaimana pentingnya kerja para perempuan desa untuk kelangsungan hidup keluarga mereka (Ellis, 1998 dalam Wulan, 2010). Salah satu startegi nafkah yang dilakukan perempuan desa untuk menyelamatkan ekonomi keluarga adalah melakukan migrasi internasional. 
Kurangnya kesempatan kerja dan banyaknya pengangguran selama krisis ekonomi telah mendorong banyak pekerja Indonesia yang mencari kerja di luar negeri. Berdasarkan data tahun 1996-2007 yang dijelaskan oleh BNP2TKI (2006) dalam IOM (2010), menggambarkan sebanyak 517.169 tenaga kerja migran meninggalkan Indonesia pada tahun 1996, sebanyak 435.222 pada tahun 2000, dan sebanyak 380.690 tenaga kerja migran meninggalkan Indonesia pada tahun 2004. BNP2TKI (2010) menambahkan bahwa peningkatan jumlah tenaga kerja kembali terjadi, tahun 2006 sebanyak 680.000 tenaga kerja migran meninggalkan Indonesia, tahun 2007 sebanyak 696.746 orang, dan tahun 2008 sebanyak 748.825 tenaga kerja migran meninggalkan Indonesia. Pada tahun 2009, sedikit mengalami penurunan, yaitu sebanyak 632.172 tenaga kerja migran yang meninggalkan Indonesia. Seiring dengan perkembangan migrasi tersebut di atas, secara global tampak bahwa fenomena migrasi perempuan diindikasikan semakin mendominasi perkembangan tersebut.

Secara ekonomis, usaha pemerintah mengenai program pengiriman tenaga kerja Indonesia ke luar negeri tidaklah sia-sia karena peningkatan jumlah TKI berarti peningkatan devisa negara serta pengurangan jumlah pengangguran. Salah satu isu penting terkait dengan migrasi adalah dampak ekonomi, khususnya aspek remitan. Penggunaan istilah "ekspor tenaga kerja" memunculkan harapan agar para pekerja migran membawa remitan tidak hanya bagi keluarganya tetapi juga untuk negara (Wulan, 2010). Hasil remitansi dari TKI, tercatat sekitar US\$1,2 milyar setiap tahunnya dari tahun 1998 hingga 1999, dan meningkat sampai hampir US\$2 milyar pada tahun 2001. Pada tahun 2002 jumlah remitansi mencapai US\$2,1 milyar, tahun 2003 sebesar US\$1,49 milyar dan menurun kembali di tahun 2004 hingga US\$1 milyar seiring dengan menurunnya jumlah pekerja migran Indonesia. Tahun 2008, total remitansi diperkirakan mencapai US\$6,6 milyar, namun secara riil, total remitansi lebih besar lagi karena banyak remitansi yang tidak tercatat (Buchori, 2006). Beberapa penemuan penelitian menunjukkan bahwa remitan yang diperoleh para migran, umumnya dikirimkan ke daerah asal, diharapkan dapat menjadi penghasilan yang bisa diinvestasikan dan digunakan ketika mereka kembali, sehingga mampu meningkatkan status mereka di dalam masyarakatnya (Chant, 1998; Deans, 2006; Ramos, 2002 dalam Mukbar, 2009).

Desa Pusakajaya yang terletak di Kabupaten Subang Jawa Barat merupakan desa di mana penduduknya sering melakukan migrasi ke luar negeri. Dirjen Benapenta Departemen Tenaga Kerja Republik Indonesia tahun 2000 sebagaimana dikutip Kustini (2002) menjelaskan bahwa Kabupaten Subang merupakan kabupaten kelima terbanyak mengirimkan tenaga kerja ke luar negeri di daerah Jawa Barat. Belum banyaknya diteliti mengenai migrasi internasional di daerah Subang, maka penelitian ini merupakan usaha memahami gerak penduduk masyarakat perdesaan di Desa Pusakajaya Kabupaten Subang khusus- nya perempuan ke luar negeri yang merupakan fenomena migrasi internasional. Fenomena ini akan terus berlanjut dan diperkirakan akan meningkat pada masa yang akan datang. Kajian mengenai migrasi internasional menarik dan penting dilakukan untuk mengetahui penyebab terjadinya migrasi internasional pada perempuan desa serta melihat pemanfaatan remitan yang dilakukan oleh keluarga migran.

\section{Perumusan Masalah}

Berdasarkan latar belakang, rumusan masalah dari penelitian ini adalah 1) apa faktor penyebab perempuan desa melakukan migrasi internasional? dan 2) bagaimana pemanfaatan remitan di rumah tangga migran?

\section{Tujuan Penelitian}

Tujuan penelitian dirumuskan sebagai berikut 1) mengkaji faktor penyebab perempuan desa melakukan migrasi internasional dan 2) mengkaji pemanfaatan remitan dalam rumah tangga migran.

\section{Kegunaan Penelitian}

Penelitian ini berguna untuk 1) menambah wawasan serta ilmu pengetahuan bagi peneliti dalam mengkaji secara ilmiah mengenai faktor-faktor yang menyebabkan terjadinya migrasi internasional yang dilakukan oleh perempuan desa dan pemanfaatan remitan; 2) menambah literatur bagi kalangan akademisi dalam mengakaji masalah migrasi internasional; 3) acuan dalam pelaksanaan pemberdayaan perempuan perdesaan bagi kalangan nonakademisi, masyarakat, swasta, dan pemerintah; dan 4) acuan bagi Pemerintah dalam penetapan kebijakan mengenai Tenaga Kerja Indonesia.

\section{PENDEKATAN TEORITIS}

\section{Tinjauan Pustaka}

\section{Migrasi Internasional dan Faktor yang Mem- pengaruhinya}

Ananta (1996) dalam Roganda (2004) menyebutkan, migrasi tenaga kerja terjadi karena adanya perbedaan antarnegara, terutama dalam memperoleh kesempatan ekonomi. Respon masyarakat terhadap perbedaan kemampuan ekonomi telah menimbulkan kesadaran untuk melakukan migrasi ke daerah yang menjanjikan dengan adanya kesempatan kerja yang lebih baik. Pada intinya, perpindahan tenaga ini disebabkan oleh adanya perbedaan ekonomi antarnegara, rendahnya tingkat upah, sulitnya memperoleh pekerjaan yang memadai di negara berkembang serta adanya kesempatan kerja dan upah yang tinggi di negara tujuan. Faktor lain yang mempengaruhi migrasi ke luar negeri, yaitu adanya karakteristik individu yang terdiri dari umur, tingkat pendidikan, dan jenis pekerjaan (Salama, 2004). Aspek-aspek tersebut erat kaitannya dengan kebutuhan tenaga kerja dari negara penerima yang hanya membutuhkan tenaga kerja untuk sektor domestik (pembantu, baby sitter, dan lain-lain), 
yaitu diperlukan wanita muda dengan tingkat pendidikan formal yang tidak begitu diperhitungkan.

Semakin meningkatnya jumlah pekerja perempuan Indonesia, memunculkan fenomena feminisasi migrasi. Mereka ikut mengambil alih tanggung jawab ekonomi keluarga. Mereka bekerja sebagai buruh tani, buruh perkebunan, pembantu rumah tangga, pemulung, buruh pabrik, dan pekerja migran. Proses ini melanjutkan proses feminisasi kemiskinan yang merupakan proses pemiskinan perempuan secara sistematis, perempuan harus lebih berat menanggung proses beban karena kemiskinan (Wulan, 2010). Berdasarkan persentase, dimulai tahun 1996, jumlah tenaga kerja perempuan tercatat 55,8\% dari 517.169 pekerja migran Indonesia, tahun 2000 jumlah tenaga kerja perempuan tercatat $68,3 \%$ dari 435.222 pekerja migran Indonesia, dan pada tahun 2004, jumlah tenaga kerja perempuan tercatat $77,9 \%$ dari 380.700 pekerja migran Indonesia. Walaupun jumlah pekerja migran Indonesia pada tahun ini mengalami penurunan, namun pekerja migran perempuan masih mendominasi migrasi internasional tersebut (BNP2TKI, 2006 dalam IOM, 2010). Kemudian pada tahun 2007, pekerja migran Indonesia meningkat kembali, dengan persentase jumlah tenaga kerja perempuan sebanyak $78 \%$ dari 696.746 pekerja migran Indonesia, tahun 2008, jumlah tenaga kerja perempuan tercatat $73,3 \%$ dari 748.825 pekerja migran Indonesia. Pada tahun 2009, walaupun jumlah tenaga kerja migran Indonesia sedikit mengalami penurunan, namun tenaga kerja perempuan mendominasi dengan persentase $83,7 \%$ dari 632.172 pekerja migran Indonesia (BNP2TKI 2010).

Malini (2002) dalam Warsito (2010) menambahkan, ada beberapa pendorong Tenaga Kerja Wanita (TKW) ingin bekerja keluar negeri antara lain 1) dorongan ekonomi, karena kebutuhan hidup yang semakin tinggi; 2) semakin sempitnya lahan pertanian sebagai mata pencaharian mereka sebagai petani; 3) lapangan kerja dalam negeri sempit serta upah yang rendah, sedangkan di luar negeri upahnya tinggi hingga tujuh kali lipat; 4) karena alasan sosial berupa pendidikan yang rendah; 5) demonstration effect, di mana mereka melihat tetangganya hidup enak dan mewah dari hasil bekerja di luar negeri; dan 6) faktor demografi usia muda membuat mereka ingin mempunyai uang yang banyak.

Wulan (2010) merangkum berbagai pendekatan dalam menjelaskan proses migrasi, seperti pendekatan teori ekonomi (Todaro 1978), pendekatan psikologi (Fawcett 1978), dan pendekatan demografi dan geografi (Lee 1970; Hugo 1975; dan Mantra 1981). Secara garis besar, Levitt (1996) dalam Wulan (2007) melihat proses migrasi berdasar tiga teori. Teori pertama adalah neoklasik yang melihat hubungan positif antara migrasi dan pembangunan. Teori berikutnya, yaitu struktur historis yang cenderung lebih pesimis melihat relasi antara migrasi dan pembangunan dan teori terakhir yang menjembatani teori neoklasik dan struktural historis, yaitu migrant network yang menekankan pentingnya jaringan sosial dan rumah tangga. Melihat pengambilan keputusan bermigrasi di tingkat individu dari perspektif geografi, dipengaruhi oleh empat faktor, yaitu 1) faktor-faktor yang ada di daerah asal; 2) faktor-faktor yang terdapat di daerah tujuan; 3) faktor penghalang migrasi; dan 4) faktor individu pelaku migrasi (Lee 1984).

Buchori (2006) menjelaskan data mengenai tingginya permintaan terhadap tenaga kerja wanita di sektor domestik dimulai pada akhir tahun 1970-an, di mana ketika itu terjadi boom minyak di Timur Tengah dan Arab Saudi menjadi negara tujuan utama migran. Kemudian sekitar tahun 1990, negara tujuan pekerja migran bertambah pada negara-negara Asia Tenggara dan Asia Pasifik akibat dibukanya peluang kerja oleh Pemerintah untuk wilayah-wilayah tersebut. Pada tahun 2004, jumlah pekerja migran perempuan di Malaysia lebih sedikit dari jumlah pekerja migran laki-laki, sedangkan di Arab Saudi kebalikannya, dengan jumlah pekerja migran perempuan di Malaysia sebanyak 49\%, dan di Arab Saudi sebanyak 94\% dari total pekerja migran Indonesia yang tercatat.

\section{Migrasi sebagai Strategi Nafkah Keluarga}

Semakin sempitnya lahan pertanian dan tingginya tingkat konversi lahan ke nonpertanian ${ }^{1}$, serta relatif kecilnya pendapatan dari usahatani, mencerminkan keterbatasan (miskin secara ekonomi) yang umum melekat pada petani, sehingga rumah tangga petani melakukan strategi nafkah dengan berupaya memanfaatkan berbagai sumber daya yang dimiliki dalam upaya untuk bertahan hidup (Scoones, 1998). Kurang mencukupinya pendapatan dari usahatani semata memicu rumah tangga petani miskin untuk mencari tambahan pendapatan dari luar pertanian. Pekerjaan nonformal, seperti tukang/buruh bangunan, dagang, industri rumah tangga, PRT (Pembantu Rumah Tangga), pengamen, pengemis, pemulung, atau menjadi TKI (Tenaga Kerja Indonesia), mengindikasikan terdapatnya diversifikasi usaha rumah tangga petani sebagai sumber pendapatan di perdesaan. Selain diversifikasi usaha (pola nafkah ganda) tersebut, usaha lainnya yang dilakukan mereka adalah migrasi (rekayasa spasial). Effendi (2004) mengungkapkan bahwa gejala mobilitas dan migrasi pekerja yang terjadi di negara-negara sedang berkembang merupakan suatu strategi untuk mempertahankan kelangsungan rumah tangga petani. Fenomena baru yang kemudian muncul di perdesaan, yaitu lapisan bawah dan menengah di perdesaan mampu menjawab tantangan hidup dengan pergi ke luar negeri untuk bekerja dan sebagian besar gajinya dikirim kembali ke desa asal.

Effendi (2004) mengungkapkan bahwa mobilitas pekerja perlu dilihat sebagai salah satu strategi mempertahankan kelangsungan hidup rumah tangga perdesaan untuk merespon perubahan-perubahan cara produksi sebagai akibat perluasan sistem pasar dan tidak meratanya akses untuk

${ }^{1}$ Soemaryanto. 2001. Dapat diakses dari: http://pse.litbang.deptan.go.id/ind/pdffiles/ART5-2c.pdf 
menguasai faktor-faktor produksi. Dalam Sosiologi Nafkah, Dharmawan (2006) memberikan penjelasan bahwa livelihood memiliki pengertian yang lebih luas daripada sekedar means of living yang bermakna sempit mata pencaharian. Dalam Sosiologi Nafkah, pengertian strategi nafkah lebih mengarah pada pengertian livelihood strategy (strategi penghidupan) daripada means of living strategy (strategi cara hidup). Strategi nafkah bisa berarti cara bertahan hidup atau memperbaiki status kehidupan. Strategi nafkah adalah taktik dan aksi yang dibangun oleh individu maupun kelompok dalam rangka mempertahankan kehidupan mereka dengan tetap memperhatikan eksistensi infrastruktur, struktur sosial, dan sistem nilai budaya yang berlaku.

Merujuk pada Scoones (1998), dalam penerapan strategi nafkah, rumah tangga petani memanfaatkan berbagai sumber daya yang dimiliki dalam upaya untuk dapat bertahan hidup. Scoones membagi tiga klarifikasi strategi nafkah (livelihood strategy) yang mungkin dilakukan oleh rumah tangga petani, yaitu 1) rekayasa sumber nafkah pertanian, yang dilakukan dengan memanfaatkan sektor pertanian secara efektif dan efisien baik melalui penambahan input eksternal, seperti teknologi dan tenaga kerja (intensifikasi), maupun dengan memperluas lahan garapan (ekstensifikasi); 2) pola nafkah ganda (diversifikasi), yang dilakukan dengan menerapkan keragaman pola nafkah dengan cara mencari pekerjaan lain selain pertanian untuk menambah pendapatan, atau dengan mengerahkan tenaga kerja keluarga (ayah, ibu, dan anak) untuk ikut bekerja-selain pertanian-dan memperoleh pendapatan; 3) rekayasa spasial (migrasi), merupakan usaha yang dilakukan dengan menggunakan mobilitas ke daerah lain di luar desanya, baik secara permanen maupun sirkuler untuk memperoleh pendapatan.

Kontribusi perempuan dalam mencari nafkah rumah tangga (dalam hal ini menjadi buruh migran perempuan), dalam kajian livelihood strategies ini merupakan suatu bentuk keterpaksaan akibat ketidakmampuan kepala rumah tangga berperan sebagai pencari nafkah bagi keluarga. Ketika secara ekonomi kepala keluarga tidak mampu mengangkat perekonomian keluarga, maka anak laki-laki maupun anak perempuan menjadi pencari nafkah yang lain. Mekanisme ini dikenal sebagai strategi bertahan hidup yang menjelaskan bahwa migrasi merupakan salah satu strategi diantara strategi-strategi yang lain (Ellis, 2000 dalam Wulan, 2010). Bagi rumah tangga yang mengirimkan angota keluarganya untuk bekerja di daerah lain dan melakukan mobilitas nonpermanen memiliki probabilitas miskin yang lebih rendah dibandingkan mereka yang stayer (Toesilaningsih 2010).

\section{Remitan}

Pada awalnya pengertian remitan adalah pengiriman uang atau barang (Caldwell, 1969 dalam Murdiyanto, 2001). Dalam penelitian di Ghana itu Caldwell menyatakan bahwa arus balik yang berupa uang dan barang merupakan aspek yang paling penting dengan adanya arus migrasi keluar dilihat dari segi ekonomi. Selain remitan berupa uang dan barang, Wulan (2010) menyebutkan bahwa remitan dapat berupa gagasan atau ide-ide, pengetahuan, dan pengalaman baru yang diperoleh selama bekerja di kota.

Menurut Salama (2004), pengaruh migrasi internasional terhadap kesejahteraan rumah tangga ditandai dengan adanya pengiriman remitan oleh migran. Remitan tersebut diantaranya digunakan untuk memperbaiki rumah, pendidikan anak, kesehatan keluarga, dan untuk modal usaha. Kiriman (remitan) merupakan komponen utama dalam melestarikan ikatan dengan daerah asal. Selain itu, uang kiriman dapat menopang pendapatan rumah tangga yang ditinggalkan di daerah asal. Uang kiriman umumnya tidak diinvestasikan ke lahan pertanian, tetapi dibelanjakan untuk keperluan sosial atau kebutuhan konsumtif (Forbes, 1986 dalam Effendi, 2004). Hal berbeda disimpulkan oleh Hadisupadmo (1991) dalam Murdiyanto (2001), dalam penelitiannya di Gunung Kidul, Hadisupadmo menyimpulkan bahwa alokasi remitan tidak hanya untuk kebutuhan konsumtif belaka, tetapi juga diinvestasikan dalam jangka panjang, seperti membiayai sekolah anak-anak, meningkatkan produksi pertanian, membeli ternak, membeli lahan pertanian dan sebagainya. Di Desa Pringgading Lombok Timur, keluarga migran memanfaatkan remitan untuk memperbaiki rumah, karena rumah dianggap sebagai simbol keberhasilan migran, disamping dapat meningkatkan status sosialnya dalam masyarakat (Tamtiari, 1999 dalam Zid, 2010). Hal serupa diungkapkan Hugo (1981), rumah merupakan suatu simbol kekayaan dan gengsi di perdesaan Jawa Barat dan suatu hal yang penting bagi migran karena ini merupakan suatu simbol kesuksesan bekerja di kota yang paling terlihat.

Pada beberapa kondisi, banyak keluarga migran yang mengandalkan remitan sebagai penghasilan utama dalam keluarganya, namun remitan bisa jadi merupakan sumber pendapatan lain dalam rumah tangganya, baik melalui diversifikasi usaha per individu maupun mata pencaharian lain dari setiap anggota rumah tangga (Mulyoutami, 2003 dalam Mukbar, 2009).

Remitan dapat membantu distribusi modal ke perdesaan, terutama peluang berusaha dan bekerja. Kolopaking (2000) dalam Zid (2010) dalam penelitiannya di Wargabinangun Cilacap menemukan pola khas penggunaan uang yang dilakukan keluarga migran, yaitu untuk memperbaiki rumah, membeli motor, ternak, tanah, dan membiayai pendidikan anak atau saudara. Mantra (1989) dalam Mukbar (2009) menunjukkan kesimpulan secara umum tentang pola investasi pendapatan migran, yaitu a) sebagian besar investasi digunakan untuk investasi materi. Hal ini menggambarkan keinginan untuk memiliki barang, baik yang bergerak maupun tidak bergerak, sebagai simbol status sosial yang berperan penting bagi sebagian migran; b) penggunaan investasi untuk pendidikan pun menjadi salah satu hal yang penting bagi 
sebagian migran yang dilihat dari tingginya pendidikan anak/adik para migran; c) sebagian kecil migran melakukan investasi pendapatan dalam bentuk investasi modal, baik untuk pembukaan usaha ataupun pengembangan usaha; d) kemudian investasi sosial, seperti menyantuni orang tua.

\section{Kerangka Pemikiran}

Secara ringkas alur penelitian digambarkan dalam kerangka pemikiran seperti Gambar 1.

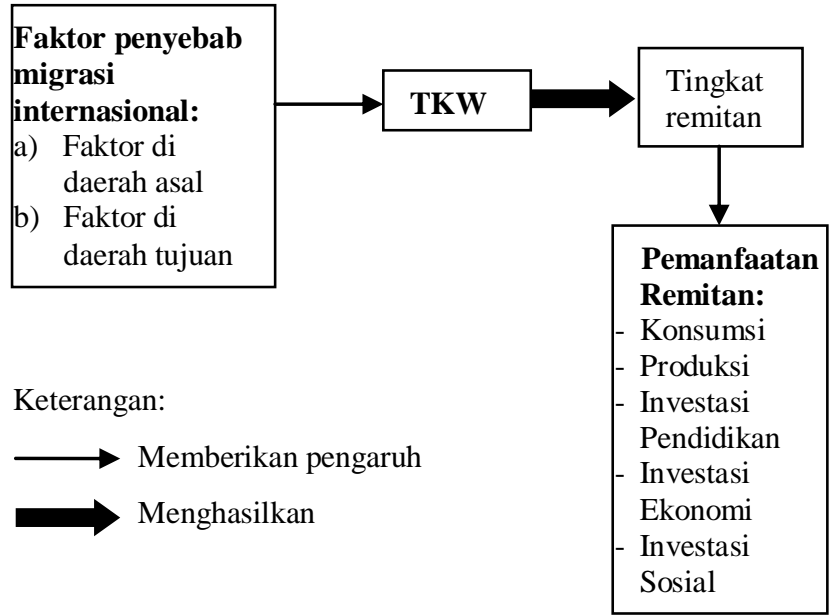

Gambar 1. Kerangka Pemikiran

Migrasi merupakan usaha yang dilakukan perempuan desa untuk memperoleh pendapatan dan membantu meningkatkan status sosial keluarga migran. Lee (1984) dalam teorinya "Dorong-Tarik" (Push-Pull Theory) menerangkan tentang proses pengambilan keputusan untuk bermigrasi yang dipengaruhi oleh empat faktor, yaitu faktor-faktor yang terdapat di daerah asal, faktor-faktor yang terdapat di daerah tujuan, faktor-faktor rintangan, dan faktor-faktor pribadi. Dalam penelitian ini akan dijelaskan dua faktor penyebab utama, yaitu faktor-faktor di daerah asal dan faktor-faktor di daerah tujuan.

Remitan yang dihasilkan migran tersebut diduga dipengaruhi oleh lamanya waktu dan negara tujuan. Remitan dapat digunakan sebagai bentuk investasi dalam proses produksi yang menguntungkan. Hal ini pun membuktikan mengenai hubungan positif antara remitan dengan bentuk investasi. Mantra (1989) dalam Mukbar (2007) menjelaskan tentang pola investasi pendapatan migran, yaitu a) sebagian besar investasi digunakan untuk investasi materi; b) penggunaan investasi untuk pendidikan; c) sebagian kecil migran melakukan investasi pendapatan dalam bentuk investasi modal; d) kemudian investasi sosial. Dalam penelitian ini, pemanfaatan remitan dibagi menjadi tiga, yaitu a) konsumsi yang meliputi konsumsi primer (sandang, pangan, dan papan), konsumsi sekunder (membayar hutang, biaya, kesehatan, hajatan, dan lain-lain), dan konsumsi tersier; b) produksi; dan c) investasi pendidikan (formal dan informal), investasi ekonomi, dan investasi sosial (sumbangan migran untuk pembangunan desa).

\section{Hipotesis Penelitian}

Hipotesis dalam penelitian ini adalah:

1. diduga kondisi di daerah asal, seperti ketidaktersediaan lapangan pekerjaan dan kondisi di daerah tujuan yang menyediakan lapangan pekerjaan dengan upah yang tinggi menjadi faktor penyebab yang kuat perempuan desa melakukan migrasi;

2. diduga remitan dalam rumah tangga migran akan dialokasikan dalam pemenuhan kebutuhan konsumsi, produksi, investasi pendidikan, investasi ekonomi, dan investasi sosial, serta membentuk pola umum, yaitu untuk pemenuhan kebutuhan konsumsi.

\section{PENDEKATAN LAPANGAN}

\section{Waktu dan Tempat Penelitian}

Pemilihan lokasi ini dilakukan secara sengaja (purposive), yaitu Desa Pusakajaya, Kecamatan Pusakajaya, Kabupaten Subang, Propinsi Jawa Barat. Alasan dipilihnya Desa Pusakayajaya sebagai lokasi penelitian, yaitu karena 1) Kabupaten Subang merupakan kabupaten kelima terbanyak mengirimkan tenaga kerja ke luar negeri di daerah Jawa Barat ${ }^{2}$; 2) Desa Pusakajaya merupakan desa di mana penduduknya sering melakukan migrasi ke luar negeri; 3) kedekatan lokasi penelitian dengan tempat tinggal peneliti menjadi bahan pertimbang-an apabila terjadi kekurangan data, sehingga mem-permudah akses untuk keluar-masuk lokasi penelitian; 4) belum banyaknya diteliti mengenai migrasi internasional di daerah Subang. Penelitian di lapangan berlangsung pada April 2011 sampai dengan Juni 2011.

\section{Metode Penelitian}

Metode dalam penelitian ini, yaitu kombinasi antara penelitian penjelasan (explanatory research) dan penelitian deskriptif (descriptive research). Penelitian ini mengambil sampel dari satu populasi dan menggunakan kuesioner sebagai alat pengumpulan data yang pokok atau disebut penelitian jenis survei (Singarimbun, 1989). Penelitian ini melihat kehidupan rumah tangga buruh pekerja perempuan yang melakukan migrasi internasional dan pemanfaatan remitan dalam rumah tangganya.

\section{Jenis dan Sumber Data}

Sumber data dalam penelitian ini adalah data primer dan data sekunder. Data primer ini diperoleh melalui wawancara kepada responden yang telah ditentukan. Adapun data sekunder didapatkan dari dokumentasi dan studi literatur yang berkaitan dengan tujuan penelitian, seperti buku, artikel, skripsi, tesis, disertasi, data potensi desa dan lainnya. Dalam upaya memperkaya data dan lebih memahami fenomena sosial yang diteliti, terdapat usaha untuk menambah informasi kualitatif pada data kuantitatif menggunakan panduan wawancara berupa

\footnotetext{
${ }^{2}$ Dirjen Binapenta Departemen Tenaga Kerja Republik
} Indonesia tahun 2000 sebagaimana dikutip Kustini (2002). 
kuesioner dan slip kertas sebagai tempat mencatat hasil wawancara mendalam.

Jenis data kuantitatif digunakan untuk mencari informasi faktual secara detail tentang hal-hal yang sedang menggejala dan mengidentifikasi masalah-masalah atau untuk mendapatkan justifikasi keadaan dan kegiatan-kegiatan yang sedang berjalan, sedangkan pengumpulan data kualitatif dilakukan dengan metode wawancara mendalam terhadap tokoh masyarakat setempat, responden, serta informan. Hasil wawancara dicatat dalam catatan harian lapangan yang didokumentasikan oleh peneliti (Wahyuni dan Muljono, 2009).

\section{Teknik Penentuan Responden}

Pada penelitian ini, terdapat dua subjek penelitian, yang terdiri dari informan dan responden. Pemilihan informan dilakukan secara sengaja (snowball sampling). Pemilihan informan kunci didasarkan pada asumsi bahwa mereka adalah orang-orang yang mengetahui secara mendalam terkait permasalahan migrasi penduduk khususnya mobilitas internasional di desa tersebut. Para informan dalam penelitian ini antara lain mantan pejabat desa, pemimpin formal (aparat desa/dusun), sponsor, dan orang yang pernah melakukan migrasi internasional tetapi sekarang telah kembali ke desa (migran kembali). Pengumpulan data dari informan dilakukan melalui wawancara bebas. Data yang dikumpulkan dari informan meliputi pandangan mengenai migrasi internasional tenaga kerja, sejarah migrasi internasional tenaga kerja yang dilakukan perempuan desa, perubahan desa, perkembangan sosial ekonomi, dan pandangan mengenai masa depan masyarakat Desa Pusakajaya.

Populasi dalam penelitian ini, yaitu seluruh rumah tangga di Desa Pusakajaya yang salah satu anggota keluarganya ada yang pernah bekerja sebagai tenaga kerja wanita di luar negeri. Adanya kendala bahwa migran yang ke luar desa tidak melakukan pemberitahuan terlebih dahulu ke Desa Pusakajaya, sehingga sulit didapatkan data yang pasti mengenai jumlah populasi. Kemudian untuk mengambil unsur sampling dalam menentukan responden, dibuatlah kerangka sampling. Kerangka sampling dari penelitian ini adalah semua migran, yakni Tenaga Kerja Wanita (TKW) yang pernah bekerja di luar negeri dan saat ini berada di daerah asal (Pusakajaya) dengan ketentuan lama bekerja sama dengan atau lebih dari empat tahun. Alasan ditentukannya lama waktu migran dengan batas sama dengan atau lebih dari empat tahun adalah karena diasumsikan bahwa selama waktu tersebut jumlah remitan yang dimanfaatkan oleh migran dan keluarganya akan menunjukkan hasil berupa investasi. Hal lain yang perlu diperhatikan juga, yaitu responden dalam satu keluarga tidak diperkenankan. Hal ini dimaksudkan agar tidak terjadi data keluarga yang tumpang tindih. Setelah dilakukannya pembatasan kerangka sampling seperti ini, didapatkan 91 orang TKW yang memenuhi kriteria seperti disebut di atas. Teknik yang digunakan dalam mendapatkan seluruh kerangka sampling tersebut adalah teknik snowball. Teknik ini dipilih karena tidak terdapat data pasti mengenai jumlah penduduk yang melakukan mobilitas ke luar desa, sehingga peneliti harus bertanya kepada aparat desa atau penduduk lainnya yang kemudian akan menunjuk subyek lainnya. Setelah kerangka sampling terkumpul, diambil 33 orang untuk dijadikan sampel dalam penelitian ini. Pemilihan responden tersebut dilakukan dengan teknik sampel acak sederhana dengan menggunakan program Microsoft Exel.

\section{Pengolahan dan Analisis Data}

Data yang diperoleh secara kuantitatif melalui kuesioner, kemudian diolah dengan menggunakan program Microsoft Excel 2007. Tahap pertama dilakukan pengkodean terhadap data. Pengkodean data dilakukan dengan pemberian simbol-simbol angka kepada jawaban- jawaban tertentu, hal ini dilakukan untuk memudahkan penyimpanan data dalam komputer. Setelah pengkodean, tahap selanjutnya adalah perhitungan persentase jawaban responden untuk membuat tabel frekuensi, grafik, dan tabulasi silang, kemudian diringkas dan dilakukan analisis deskriptif dengan mereduksi hasil pembicaraan dengan responden atau informan.

\section{GAMBARAN UMUM LOKASI PENELITIAN}

\section{Lokasi dan Kondisi Fisik Desa}

Desa Pusakajaya merupakan salah satu desa yang berada di Kecamatan Pusakajaya, Kabupaten Subang, Propinsi Jawa Barat. Desa ini memiliki batas-batas administrasi wilayah desa, yaitu sebelah utara berbatasan dengan Desa Pusakaratu, sebelah selatan berbatasan dengan Desa Bojongjaya, sebelah barat berbatasan dengan Desa Kotasari, dan sebelah timur berbatasan dengan Desa Kebondanas. Luas Desa Pusakajaya, yaitu 618,7 ha berupa daratan. Sebagian besar tanah di Desa Pusakajaya, yaitu sebanyak 514 ha dimanfaatkan untuk persawahan, sedangkan 88 ha digunakan untuk permukiman penduduk dan prasarana umum lainnya. Jika ditinjau berdasarkan letak geografisnya, Desa Pusakajaya berupa bentangan lahan dataran dengan kondisi 1,8 meter dari permukaan laut, memiliki curah hujan rata-rata $1.800 \mathrm{~mm}$ per tahun dengan jumlah bulan basah sebanyak 4 bulan, dan berada pada suhu harian $23 \mathrm{~s} / \mathrm{d} 35^{\circ} \mathrm{C}$ (Potensi Desa Pusakajaya, 2010).

Secara administratif, Desa Pusakajaya terdiri dari 4 dusun, 8 RW, dan 37 RT. Dari semua dusun di Desa Pusakajaya, yaitu Mekarjaya, Pasirjati, Kedungjati, dan Mekarjati sudah dapat ditempuh kendaraan beroda dua dan beroda empat, walaupun belum semuanya beraspal. Sebanyak 4 dusun di Pusakajaya tersebut semuanya menjadi pemukiman penduduk yang pergi ke luar negeri sebagai Tenaga Kerja Indonesia (TKI). Sebanyak 2.178 keluarga atau $81,7 \%$ keluarga di Desa Pusakajaya tidak memiliki lahan pertanian. Mereka bekerja sebagai buruh pertanian. Sebagian lahan pertanian di Desa Pusakajaya dikuasai oleh penduduk luar daerah yang banyak menetap di Jakarta. 


\section{Kependudukan}

Berdasarkan hasil sensus terbaru (2010), Desa Pusakajaya memiliki jumlah penduduk sebanyak 10.513 orang, dengan jumlah kepala keluarga sebanyak 2.667 Kepala Keluarga (KK). Dilihat dari tingkat pendidikan penduduk Desa Pusakajaya, sebanyak 2.298 jiwa (38,6\%) tidak mengenyam pendidikan di bangku sekolah, selanjutnya penduduk yang menamatkan pendidikan Sekolah Menengah Pertama (SMP) sebanyak 1.812 jiwa (30.4\%), kemudian menamatkan pendidikan Sekolah Dasar (SD) sebesar 913 jiwa (15,3\%). Adanya kondisi kemiskinan pada sebagian masyarakat dan tingkat pemahaman yang relatif rendah tentang arti pentingnya sekolah, menyebabkan mereka yang tergolong usia pendidikan sebagian besar harus bekerja dan keluar sekolah untuk menambah pendapatan keluarga. Rentang usia penduduk Desa Pusakajaya menyebar merata, dengan komposisi laki-laki sebanyak 5.307 orang $(50,5 \%)$ dan perempuan sebanyak 5.206 orang $(49,5 \%)$.

Mata pencaharian penduduk Desa Pusakajaya sebagian besar adalah buruh tani dengan jumlah 3.708 orang atau $75,9 \%$ penduduk. Selanjutnya diikuti petani, yaitu sebanyak 518 orang, atau sekitar 10,6\%. Hal ini menunjukkan adanya suatu ketergantungan yang tinggi masyarakat Desa Pusakajaya terhadap pertanian. Banyaknya jumlah keluarga yang tidak memiliki lahan pertanian, yaitu sebanyak 2.178 keluarga.

Kurang lengkapnya data demografi desa ini, menyebabkan tidak diperolehnya data lengkap atau gam-baran mengenai penduduk yang melakukan mobilitas ke luar desa dan jenis pekerjaan yang mereka lakukan di sana, sehingga tidak diperolehnya gambaran umum tentang mobilitas perempuan ke luar desa. Data mengenai mobililitas perempuan ke luar desa didapatkan dari sponsor yang memberikan gambaran singkat secara lisan mengenai banyaknya jumlah perempuan di Desa Pusakajaya yang melakukan migrasi internasional tenaga kerja.

\section{Potensi Sarana dan Prasarana}

Prasarana transportasi darat terdiri dari jalan desa, jalan antar desa, jembatan desa, jembatan antar desa atau kecamatan. Sarana transportasi darat, meliputi angkutan umum, ojek, dan becak. Prasarana komunikasi dan informasi penduduk Desa Pusakajaya mayoritas adalah televisi dan radio. Selain itu ada pula warga yang memanfaatkan internet dan telepon genggam sebagai alat komunikasi. Desa Pusakajaya memiliki prasarana peribadatan berupa 6 buah masjid dan 32 buah mushola. Prasarana kesehatan di Desa Pusakajaya terdiri dari Polindes sebanyak 1 unit dan Posyandu sebanyak 4 unit. Sarana pendidikan di Desa Pusakajaya, yaitu gedung TK/PAUD sebanyak 3 unit, gedung SD/sederajat 4 unit, gedung SMP/sederajat 2 unit, gedung SMA/sederajat 2 unit, dan Lembaga Pendidikan Agama sebanyak 3 unit.

\section{Mobilitas Penduduk Perempuan Desa Pusakajaya}

Pengiriman buruh migran di Desa Pusakajaya dilakukan pertama kali oleh perempuan yang berstatus menikah, namun ia pergi secara mandiri tanpa ditemani suami ataupun anaknya. Pemberangkatan perempuan desa menjadi buruh migran di Desa Pusakajaya dimulai tahun 1992, di mana saat itu peminatnya hanya sedikit. Hal ini disebabkan rasa takut yang dialami calon migran ketika harus bekerja di luar negeri, tempat yang jauh dari keluarga dan daerah asalnya. Namun perubahan terjadi sekembalinya migran dari luar negeri dengan membawa keberhasilan (secara ekonomi). Migran yang berangkat ke luar negeri untuk bekerja, kembali ke daerah asal dengan membawa sejumlah uang yang tidak sedikit ke daerah asal. Sejak saat itu masyarakat Desa Pusakajaya percaya bahwa bekerja di luar negeri merupakan alternatif terbaik untuk meningkatkan ekonomi keluarga mereka. Melalui bantuan para sponsor, program pengiriman TKW ke luar negeri di Desa Pusakajaya cukup menampakkan hasil, akan tetapi setelah beberapa tahun kemudian banyak TKW yang merasa bahwa dirinya dirugikan oleh pihak sponsor.

Oleh karena itu, calon TKW yang sudah pernah melakukan migrasi internasional tenaga kerja sebelumnya, sebagian ada yang tidak lagi melalui sponsor, akan tetapi mereka lebih memilih untuk datang langsung ke PT yang menangani pengiriman TKW. Kerugian ini dirasa-kan oleh TKW karena upah yang mereka terima saat bekerja di luar negeri mendapat potongan dari pihak sponsor. Perempuan yang bekerja ke luar negeri menampakkan hasil secara fisik, yaitu dalam hal pembangunan rumah, di mana dulunya sebelum migran berangkat ke luar negeri, banyak bangunan rumah yang belum permanen atau masih menggunakan bilik sebagai dinding namun setelah kembali dari bekerja di luar negeri, bangunan rumah menjadi permanen dan sudah menggunakan MCK milik pribadi.

\section{FAKTOR PENYEBAB PEREMPUAN DESA MELAKUKAN MIGRASI INTERNASIONAL}

Lee (1984) dalam teorinya "Dorong-Tarik" (Push-Pull Theory) berpendapat bahwa migrasi dari desa ke kota disebabkan oleh faktor pendorong di desa dan faktor penarik di kota. Faktor di daerah asal merupakan keadaan-keadaan di daerah asal yang dirasakan responden dan memungkinkan untuk mendorong mereka melakukan migrasi tenaga kerja ke luar negeri. Umumnya faktor ekonomi merupakan faktor utama masyarakat desa menjadi TKW. Raharto (1999) mengemukakan hasil studi di Desa Bantala bahwa alasan ekonomi ini juga dipengaruhi oleh kurangnya kesempatan kerja yang sangat berkaitan erat dengan kondisi geografi di daerah asal, kemudian adanya kesempatan untuk bekerja ke luar negeri dengan upah yang lebih tinggi, mampu mengatasi hal tersebut. Dalam bab ini akan dijelaskan bagaimana kondisi di daerah asal dan daerah tujuan yang menjadi 
alasan bagi perempuan desa untuk melakukan migrasi tenaga kerja internasional.

\section{Faktor di Daerah Asal}

Ada berbagai motif yang menjadi dasar seseorang melakukan migrasi. Berdasarkan data yang diperoleh di lapang, alasan responden melakukan migrasi adalah karena tidak mempunyai lahan pertanian sebesar $100 \%$. Responden merasa penghasilan suami sebagai buruh pertanian yang tidak mempunyai lahan pertanian dirasa kurang dan ketersediaan lapangan pekerjaan yang minim bagi perempuan di Desa Pusakajaya pun menjadi alasan bagi perempuan di Desa Pusakajaya untuk bekerja ke luar negeri.

Sebanyak 78,8\% responden merasa Desa Pusakajaya sebagai daerah asalnya tidak menyediakan cukup pekerjaan bagi mereka. Kebanyakan dari mereka jika tidak mempunyai keterampilan yang cukup, sangat sulit untuk mendapat pekerjaan. Beberapa responden ada yang bekerja sebelum berangkat menjadi TKW, beberapa diantaranya bekerja sebagai penjahit dan pedagang, namun mereka merasa upah yang diperoleh masih rendah, sebanyak $100 \%$ responden mengatakan upah yang diterimanya bekerja di desa masih rendah. Menjadi TKW berarti mampu menghasilkan pendapatan dan membantu suami dalam mencari nafkah bagi keluarga, dan ini merupakan kebanggaan tersendiri bagi mereka karena mereka mampu menyekolahkan anak-anak mereka ke jenjang yang lebih tinggi.

Di desa ini juga masih terdapat pengajian-pengajian yang sangat aktif dan memungkinkan perempuan bersosialisasi dengan perempuan lainnya. Pembangunan gedunggedung sekolah dan pasar desa menjadi suatu kemajuan desa yang penting bagi para penduduknya. Hal tersebut merupakan faktor penahan yang mampu menahan perempuan desa bermigrasi, namun faktor-faktor di daerah asal yang dinilai bisa menjadi faktor penahan bagi terjadinya migrasi internasional perempuan desa memiliki kekuatan yang lemah. Penduduk Desa Pusakajaya mempunyai mata pencaharian di sektor pertanian. Mereka kebanyakan bekerja sebagai buruh tani, sedangkan istrinya ikut membantu suami menandur sawah. Penduduk di desa ini tidak banyak yang memiliki lahan pertanian karena kebanyakan lahan mereka sudah dijual kepada pihak luar, seperti orang Jakarta, Pamanukan, dan Indramayu, atau lahan pertanian tersebut dibeli oleh orang desa yang memang memiliki status sosial yang tinggi atau termasuk dalam golongan petani kalangan atas yang sudah memiliki banyak lahan pertanian. Bagi mereka yang memang tidak mempunyai lahan pertanian, bekerja pada sektor di luar pertanian dinilai lebih menjamin dan menguntungkan. Pekerjaan tersebut, seperti sektor formal (satpam dan guru), berdagang, jasa transportasi (ojek dan becak), dan kuli atau tukang bangunan. Bekerja sebagai buruh tani dan mengandalkan sektor lain di luar pertanian pun banyak dilakukan oleh suami migran. Peralihan pekerjaan dari sektor pertanian ke luar sektor pertanian disebabkan tidak mencukupinya pendapatan di sektor pertanian, usaha tani tersebut umumnya musiman, dan banyak mengandung resiko serta ketidakpastian (Mubyarto, 1985 dalam Mukbar, 2009).

Tingkat upah yang diterima dari penghasilan bekerja sebagai buruh tani termasuk rendah. Mereka yang bekerja sebagai buruh perorangan mendapat upah yang lebih tinggi dibanding mereka yang bekerja secara borongan. Upah buruh tani perorangan berkisar antara Rp40.000,00 per hari, bekerja seharian dan tanpa biaya makan. Jika mereka bekerja borongan, seperti menandur, perbaikan lahan, dan upah buruh panen, mendapat upah sebesar Rp400.000,00-Rp500.000,00 per bahu. Hasil ini akan dibagi sesuai jumlah orang yang bekerja. Rata-rata upah yang mereka terima dengan bekerja secara borongan, yaitu Rp20.000,00-Rp30.000,00. Berbeda dengan petani yang menyewa lahan/menggarap lahan orang lain, mereka memperoleh hasil bagian setelah panen terkumpul dan dibagi dua dengan pemilik setelah dikurangi dengan modal. Kemudian jika ditambah dengan bekerja sebagai buruh bangunan, rata-rata per hari memperoleh penghasilan Rp50.000,00-Rp60.000,00.

Bagi perempuan, bekerja membantu suami merupakan suatu kebanggaan, namun pekerjaan yang tersedia bagi perempuan di Desa Pusakajaya memang terbatas. Di Kabupaten Subang dan Purwakarta terdapat banyak pabrik, namun tingkat pendidikan dan keterampilan yang rendah tidak memungkinkan mereka memasuki sektor tersebut. Bagi mereka, menjadi TKI merupakan keputusan yang tepat, yang dipicu fakta/berita bahwa bekerja ke luar negeri memberi prospek dan gaji yang lebih baik. Fakta demikian dapat menjadi penarik bagi pekerja migran sebagai upaya memperoleh pendapatan dalam ketidakberdayaan di negara asal.

\section{Faktor di Daerah Tujuan}

Wiyono (1994) dalam Pardede (2008), menyatakan faktor-faktor penarik untuk melakukan migrasi internasional dilihat dari daerah asalnya, yaitu permintaan tenaga kerja, letak geografis, dan kesamaan budaya. Kawasan Malaysia dan Singapura, daya tariknya lebih didasari letak geografis, untuk Saudi Arabia lebih didasarkan oleh keinginan para migran untuk melaksanakan ibadah haji, sedangkan untuk Hongkong dan Taiwan lebih didasarkan pada upah yang tinggi dan pengalaman kerja yang berbeda.

Berdasarkan data yang diperoleh dalam penelitian ini, terdapat beberapa alasan responden memilih negara tujuan bermigrasi. Tersedianya lapangan pekerjaan dan upah yang tinggi di negara tujuan menjadi faktor penarik utama bagi perempuan desa untuk bermigrasi. Hal ini disebabkan tujuan utama TKW bermigrasi ke luar negeri adalah bekerja membantu perekonomian keluarga. Upah yang tinggi jika dibandingkan bekerja di Indonesia dengan tingkat pendidikan yang sama, membuat mereka lebih memilih bekerja sebagai TKW ke luar negeri. 
Sebanyak $100 \%$ responden mengatakan tersedianya lapangan pekerjaan di negara tujuan dengan upah yang tinggi membuat mereka memilih untuk bermigrasi. Sebanyak $75,8 \%$ responden menyatakan keinginannya untuk cepat berangkat ke negara tujuan, tidak peduli pekerjaan apa yang ada di sana. Waktu keberangkatan dan lamanya waktu mereka berada di PT menentukan pilihan mereka untuk memilih negara tujuan.

Tingginya permintaan tenaga kerja di negara tujuan, memberikan peluang bagi migran untuk memperoleh pekerjaan di luar negeri. Kebanyakan dari responden yang berangkat ke luar negeri memang tidak mempunyai pekerjaan ketika di daerah asal. Banyaknya responden yang tidak bekerja sebelum berangkat menjadi TKW sebanyak 28 orang atau sebesar $84,8 \%$, sedangkan yang memiliki pekerjaan hanya sebanyak 5 orang atau $15,2 \%$. Pekerjaan tersebut antara lain menjahit, bertani, dan berdagang. Pekerjaan tersebut mereka miliki karena keahliannya sendiri sebelum bermigrasi. Ketika telah kembali dari bermigrasi, jumlah responden yang bekerja meningkat menjadi 10 orang atau sebesar 30,3\%. Hal ini berarti responden tersebut telah mampu melakukan investasi karena pekerjaan tersebut didapatnya dari modal selama ia bekerja menjadi migran. Pekerjaan tersebut, yaitu berdagang membuka warung atau menjual masakan.

Responden yang dulunya memang bekerja sebagai penjahit dan pedagang, setelah kembali ke daerah asal tetap melanjutkan pekerjaan yang ia lakukan sebelum menjadi TKW dengan tambahan modal yang didapatnya selama bekerja menjadi TKW, namun hal ini bukan berarti mereka tidak akan kembali lagi bekerja menjadi TKW. Seperti diungkapkan oleh salah seorang responden yang dulu bekerja sebagai pedagang kredit barang setelah kembali pun terus mengakumulasikan uangnya sebagai tambahan modal ia berdagang, namun ia menjelaskan bahwa ia masih ingin mencoba peruntungan dengan menjadi TKW ke Daerah Hongkong atau Taiwan karena pengalamannya menjadi TKW di Negara Arab Saudi atau Timur Tengah dirasa masih belum cukup. Sejauh ini responden yang tidak bekerja, menjadi ibu rumah tangga, mengandalkan tabungannya selama bekerja menjadi TKW, dan mengandalkan penghasilan dari suami atau kembali menjadi TKW.

Selain faktor ekonomi, responden memilih negara-negara Timur Tengah karena adanya keinginan untuk melaksanakan ibadah haji/umroh, mencari pengalaman bekerja di luar negeri dan kesamaan agama dengan daerah tujuan. Sebanyak 33,33\% responden memilih Negara Timur Tengah sebagai tujuan beribadah. Adanya kesamaan bahasa atau etnik dinyatakan oleh $6,06 \%$ responden. Responden yang memilih negara tujuan ke Malaysia disebabkan bahasanya yang mudah dan hampir serupa dengan bahasa Indonesia.

Selain faktor tersebut di atas, jenis pekerjaan TKW di sana juga ikut mempengaruhi responden untuk bekerja ke luar negeri. Jenis pekerjaan yang dilakukan TKW selama bekerja di luar negeri, rata-rata bekerja sebagai pembantu rumah tangga sebanyak 75,8\%. Sebanyak 21,2\% responden lainnya bekerja merawat jompo, dan 3,0\% lainnya bekerja sebagai penjahit. Banyaknya TKW yang bekerja sebagai pembantu rumah tangga tersebut disebabkan pekerjaan yang ditawarkan oleh negara tujuan adalah pembantu rumah tangga. Kemudian berdasarkan kemampuan TKW dan tingkat pendidikannya, menjadi pembantu rumah tangga adalah pilihan pekerjaan yang memang tidak banyak menuntut kemampuan, keterampilan dan tingkat pendidikan yang tinggi.

\section{Karakteristik Responden dan Keluarga}

\section{Umur}

Hubungan antara program pengiriman TKW ke luar negeri dan umur, yaitu pemerintah telah menetapkan persyaratan, yaitu minimal berusia 18 tahun atau sesuai permintaan negara tujuan (pasal 39 ayat 2/MEN/2002), di mana umur yang sudah cukup dewasa dan matang dalam bersikap dan semangat kerja yang tinggi. Saat pertama kali bekerja ke luar negeri, sebanyak $48,5 \%$ responden berada pada rentang umur $\mathrm{x} \leq 21$ tahun dan sebanyak $51,5 \%$ responden berada pada rentang umur $\mathrm{x}>21$ tahun. Berdasarkan pengakuan responden, terdapat umur responden yang kurang dari 18 tahun, yaitu termuda berumur 16 tahun ketika pertama kali berangkat menjadi TKW. Hal ini disebabkan mereka tidak mengetahui secara pasti peraturan yang menetapkan bahwa calon TKW harus berumur 18 tahun ke atas atau sesuai dengan permintaan negara tujuan. Umur responden ketika penelitian ini berlangsung, yaitu sebanyak $51,5 \%$ responden berada pada rentang umur $\mathrm{x} \leq 36$ tahun dan sebanyak $48,5 \%$ responden berada pada rentang umur $\mathrm{x}>36$ tahun.

\section{Status Pernikahan}

Seorang wanita yang sudah menikah mempunyai peranan yang komplek, yaitu sebagai istri dan ibu rumah tangga. Wanita yang sudah menikah menjadi TKW untuk membantu suaminya mencari nafkah, sedangkan wanita yang belum menikah atau janda, menjadi TKW untuk membantu perekonomian keluarganya. Dari sisi tanggung jawab, wanita yang sudah menikah memiliki tanggung jawab yang lebih besar dibanding wanita yang belum menikah, karena harus meninggalkan suami dan anaknya. Hal ini kemudian akan berdampak pada kehidupan rumah tangganya dan perkembangan anaknya, untuk itu status pernikahan berpengaruh pada keputusan migran untuk bekerja atau tidak.

Sebanyak $66,7 \%$ responden berstatus menikah. Hal ini menunjukkan adanya suatu keterkaitan responden terhadap suami dan anaknya, namun di sisi lain pernikahan juga memungkinkan responden untuk memenuhi kebutuhan hidup sehari-hari dan membiayai pendidikan sekolah anak. Kebutuhan tersebut dirasakan lebih tinggi dibanding ketika belum menikah, sehingga hal tersebut mendorong responden untuk melakukan pemenuhan kebutuhan 
hidupnya, dengan membantu suami ataupun sebagai pencari nafkah utama karena suami tidak bekerja.

Sebanyak 24,3\% responden belum menikah ketika pertama kali melakukan migrasi internasional, hal ini disebabkan keinginan responden untuk membantu perekonomian keluarga, mencari pasangan hidup, atau sekedar mencari pengalaman dan menabung untuk masa depan. Tingginya wanita berstatus menikah yang menjadi TKW menunjukkan tuntutan wanita untuk bekerja sebagai pencari nafkah membantu suami dan ketidakpuasan terhadap penghasilan suami. Ketika dilakukannya penelitian ini, sebanyak 90,9\% responden sudah menikah dan sebanyak $9,1 \%$ responden yang berstatus janda.

\section{Tingkat Pendidikan}

Kualitas TKW di Desa Pusakajaya dilihat dari tingkat pendidikan formal TKW relatif masih rendah. Dari 33 responden, sebanyak $15,2 \%$ TKW yang tidak menamatkan pendidikan di tingkat dasar (tingkat pendidikan rendah), sebanyak $51,5 \%$ responden menamatkan pendidikan tingkat dasar (tingkat pendidikan sedang), kemudian sebanyak 30,3\% responden berhasil menamatkan pendidikan tingkat SMP, dan hanya sebanyak 3,03\% responden berhasil menamatkan pendidikan di tingkat SMA (tingkat pendidikan tinggi).

Sekembalinya menjadi TKW, tidak ada satu pun TKW yang melanjutkan pendidikannya ke jenjang yang lebih tinggi. Mereka lebih memilih menginvestasikan uangnya dalam bentuk lain atau menyekolahkan anak atau adik mereka. Secara tidak langsung, bekerja menjadi TKW membawa pengalaman yang berbeda bagi mereka. Dengan belajar sedikit demi sedikit mereka mampu menguasai bahasa asing di tempat mereka bekerja.

\section{Jenis Pekerjaan Suami/Kepala Keluarga}

Dari 33 responden, sebanyak 27,3\% kepala keluarga TKW bekerja sebagai buruh tani/buruh bangunan, 18,2\% sebagai pedagang/wiraswasta, 12,1\% sebagai supir, $12,1 \%$ lainnya bekerja dengan upah tetap sebagai satpam, guru, dan pegawai koperasi, dan 9,1\% bekerja sebagai petani. Selain pekerjaan pokok ada beberapa kepala keluarga TKW yang mempunyai pekerjaan sampingan atau pekerjaan ganda, yaitu di bidang jasa dan buruh bangunan.

\section{Status Ekonomi Keluarga}

Rumah tangga responden yang memiliki penghasilan tinggi, yaitu Rp2.375.000,00-Rp3.250.000,00 sebesar $15,2 \%$ responden, sedangkan yang rumah tangga responden yang memiliki penghasilan sedang, yaitu

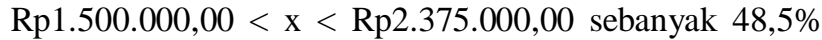
responden, dan rumah tangga yang memiliki penghasilan rendah, yaitu Rp625.000,00-Rp1.500.000,00 sebanyak $36,4 \%$ responden.

\section{Jumlah Tanggungan Ekonomi Keluarga}

Jumlah tanggungan ekonomi keluarga dilihat dari banyaknya jumlah anak yang masih sekolah dan memerlukan biaya pendidikan. Rata-rata jumlah tanggungan ekonomi keluarga TKW berdasar jumlah anak yang masih sekolah adalah dua orang. Sebanyak 63,6\% keluarga TKW mempunyai jumlah tanggungan ekonomi $<2$ orang dan 36,4\% lainnya mempunyai jumlah tanggungan ekonomi keluarga $\geq 2$ orang.

\section{Negara Tujuan dan Lama Waktu Menjadi TKW Berdasarkan Karakteristik Responden}

Responden yang berangkat pertama kali menjadi TKW dengan umur $\mathrm{x} \leq 21$ cenderung memiliki pengalaman bernegara yang lebih banyak, yaitu mereka pernah menjadi TKW di Negara Timur Tengah (Arab Saudi, Bahrein, Qatar), Asia Timur (Hongkong, Taiwan), atau Malaysia. Sebanyak 100\% responden dari 3 orang yang pernah mempunyai pengalaman bernegara ke Timur Tengah dan Asia Timur, semuanya berusia $x \leq 21$. Di usia yang tergolong muda ini pula, yaitu $\mathrm{x} \leq 21$, responden cenderung memilih negara tujuan Asia Timur, yaitu sebanyak $60 \%$ responden. Dibandingkan responden yang berusia $\mathrm{x}>21$ tahun, mereka cenderung memilih Negara Timur Tengah sebanyak $60 \%$ dan Asia Timur sebanyak $40 \%$.

Responden yang memilih Negara Timur Tengah sebagai negara tujuannya, sebanyak $72 \%$ berstatus menikah, $4 \%$ berstatus janda, dan $24 \%$ belum menikah. Responden yang memiliki pengalaman bernegara ke Timur Tengah dan Asia Timur, sebanyak 66,7\% berstatus menikah pula, sedangkan untuk responden yang memilih negara tujuan Asia Timur, sebanyak $40 \%$ berstatus menikah, $40 \%$ janda, dan $20 \%$ belum menikah. Hal ini membuktikan bahwa wanita yang bekerja sebagai TKW di luar negeri, didominasi oleh wanita yang berstatus menikah.

Responden yang memilih negara tujuan Timur Tengah, sebanyak $16 \%$ memiliki tingkat pendidikan rendah (tidak tamat SD), sebanyak $64 \%$ memiliki tingkat pendidikan sedang (tamat SD), dan sebanyak 20\% memiliki tingkat pendidikan tinggi (tamat SMP dan tamat SMA). Responden yang memilih negara tujuan Asia Timur dan Campuran, didominasi oleh responden yang memiliki tingkat pendidikan tinggi. Sebanyak $80 \%$ responden dengan tingkat pendidikan tinggi memilih negara tujuan ke Asia Timur dan sebanyak $66,7 \%$ responden dengan tingkat pendidikan tinggi memiliki pengalaman bernegara ke Negara Timur Tengah dan Asia Timur.

Berdasarkan karakteristik pribadi responden dan dibandingkan dengan lama waktu bekerja menjadi TKW, terlihat bahwa responden dengan usia $\mathrm{x} \leq 21$ sebanyak $44,4 \%$ bekerja dengan lama waktu $\mathrm{x} \leq 5$ dan sebanyak $53,3 \%$ responden bekerja dengan lama waktu $x>5$. Responden dengan usia $\mathrm{x}>21$ sebanyak 55,6\% bekerja dengan lama waktu $\mathrm{x} \leq 5$ dan sebanyak $46,7 \%$ responden bekerja dengan lama waktu $\mathrm{x}>5$. Hal ini berarti semakin 
tua umur responden, tidak menentukan bahwa semakin lama pengalaman waktu ia bekerja.

Responden yang menjadi TKW mayoritas berstatus menikah sebesar 72,2\% dengan lama waktu bekerja $\mathrm{x} \leq 5$ tahun dan sebesar $60,0 \%$ responden berstatus menikah dengan lama waktu bekerja $\mathrm{x}>5$ tahun. Responden yang bekerja dengan lama waktu $\mathrm{x} \leq 5$ tahun sebesar 50,0\% memiliki tingkat pendidikan sedang (tamat SD) dan sebesar 38,9\% responden berpendidikan tinggi (tamat SMP dan tamat SMA). Responden yang bekerja dengan lama waktu $\mathrm{x}>5$ tahun sebesar 53,3\% memiliki tingkat pendidikan sedang (tamat SD) dan sebesar 26,7\% responden memiliki pendidikan tinggi.

\section{PEMANFAATAN REMITAN}

\section{Jumlah dan Alokasi Penggunaan Remitan Migrasi Internasional}

Remitan dibutuhkan untuk memenuhi kebutuhan hidup sehari-hari. Bagi buruh migran yang perekonomiannya sangat sulit, bekerja menjadi fokus utama untuk membantu keluarga. Sebanyak $60,6 \%$ responden mengirimkan upahnya secara rutin dan sebanyak $39,4 \%$ responden mengirimkan upahnya ketika diminta saja. Migran mengirimkan remitansi ke desa sebanyak 2-8 kali dalam satu masa kontrak. Pada beberapa bulan pertama awal kontrak, sulit bagi mereka mengirimkan uang karena upah tersebut habis untuk potongan. Setiap kali kiriman, jumlah yang dikirimkan sangat bervariatif. Jumlah yang umum meraka kirimkan lewat bank setiap kali pengiriman adalah antara Rp1.000.000,00-Rp8.000.000,00. Hal ini karena ada migran yang langsung mengirimkan upahnya dalam 3-4 bulan kerja, tetapi ada juga yang menyimpannya terlebih dahulu 1-2 tahun.

Pengiriman remitan yang dilakukan migran ini akan berpengaruh terhadap pemanfaatan remitan di daerah asal. Bagi TKW yang mengirimkan remitannya rutin setiap 3-4 bulan sekali, biasanya remitan tersebut digunakan untuk pemenuhan kebutuhan konsumsi dan investasi pendidikan. Hal ini berarti keluarga TKW memanfaatkan remitan sebagai sumber penghidupan utama keluarganya. Ada pula TKW yang mengirimkan remitan hanya ketika diminta oleh keluarganya, biasanya penggunanaannya bervariasi, seperti untuk kredit motor, perbaikan rumah dan biaya kesehatan, namun tidak menutup kemungkinan bahwa TKW yang menyimpan uangnya dulu baru ketika diminta oleh keluarga mengirimkan remitan juga ikut membantu keluarganya dalam hal konsumsi.

Sebanyak 21,2\% responden mengirim remitan rendah (0$25 \%$ ), sebanyak $18,2 \%$ responden mengirim remitan sedang (26-50\%), dan sebanyak $60,6 \%$ responden mengirim remitan dengan jumlah yang besar (51-75\%) dari upah yang diterimanya bekerja sebagai buruh migran. Banyaknya responden/buruh migran yang mengirimkan upah tinggi dari upah yang ia terima selama bekerja menjadi buruh migran, hal ini disebabkan migran tersebut merupakan tulang punggung keluarganya yang mem- punyai beban tanggungan di desanya. Hal lain yang ikut mempengaruhi pengiriman remitan tersebut, yaitu permintaan khusus dari keluarganya di daerah asal, seperti biaya untuk membangun rumah, biaya perawatan orang tua yang sakit, atau gadai sawah. Lain halnya dengan migran yang mengirimkan remitan rendah (0-25\%), mereka lebih memilih menabung sendiri atau menyimpan sendiri hasil upahnya baru kemudian setelah habis masa kontrak, pulang membawa hasil upah tersebut. Hal ini biasanya dilakukan oleh buruh migran yang tidak mempunyai beban tanggungan yang besar di daerah asal atau bukan sebagai pencari nafkah utama dalam keluarga. Hugo (1983) dalam Effendi (2004) menyatakan remitan masuk cendrung semakin besar bila mobilitas pekerja berhubungan dengan strategi rumah tangga untuk mempertahankan kelangsungan hidup.

Hasil remitan yang mereka kirimkan ke daerah asal dialokasikan dalam berbagai bentuk, seperti konsumsi atau investasi. Penggunaan remitan selain untuk pemenuhan kebutuhan konsumsi, sebagian digunakan untuk memenuhi kebutuhan investasi, baik investasi pendidikan formal maupun investasi ekonomi (biaya yang dikeluarkan sebagai modal untuk memperoleh penghasilan kembali). Penggunaan utama remitan di Desa Pusakajaya ini adalah untuk keperluan konsumsi, baik meliputi konsumsi primer (sandang, pangan, papan) ataupun kebutuhan sekunder (kebutuhan nonpangan, seperti biaya pernikahan, hajatan, kesehatan, pembayaran hutang, dan lain-lain). Jika kebutuhan utama tersebut telah terpenuhi, mereka akan mulai berinvestasi, yaitu dengan membeli emas, tanah, sawah, atau ternak. Investasi lainnya yang menjadi penting bagi migran adalah investasi pendidikan. Migran mengungkapkan bahwa alasan lain mereka menjadi TKW selain untuk memenuhi kebutuhan seharihari adalah mencari biaya untuk pendidikan anakanaknya.

Pengalokasian remitan yang dilakukan responden di Desa Pusakajaya tersebut membentuk beberapa cara pemanfaatan remitan. Berdasarkan hasil penelitian di Desa Pusakajaya, sebanyak 33,3\% responden memanfaatkan remitan untuk memenuhi kebutuhan konsumsi, investasi pendidikan, dan investasi ekonomi.

Sebanyak $27,3 \%$ responden memanfaatkan remitan untuk memenuhi kebutuhan konsumsi dan investasi pendidikan, sebanyak $12,1 \%$ responden memanfaatkan remitan untuk memenuhi kebutuhan konsumsi, sebanyak 12,1\% responden memanfaatkan remitan untuk memenuhi kebutuhan konsumsi, produksi, investasi pendidikan, dan invesatsi ekonomi. Sebanyak 3,0\% responden memanfaatkan remitan hanya untuk investasi pendidikan, hal ini disebabkan kurangnya kepercayaan responden pada suaminya, sehingga ia menitipkan hasil upahnya pada saudaranya dan dipergunakan hanya untuk biaya pendidikan anaknya. Investasi pendidikan yang diberikan responden pada anaknya ialah pendidikan formal, sedangkan investasi ekonomi yang dilakukan responden, 
yaitu seperti membeli tanah/pekarangan, ternak, sawah, atau untuk memperluas dan membuka usaha. Responden yang memanfaatkan hasil upahnya untuk kebutuhan konsumsi saja sebanyak 12,1\%. Tabel 1 menggambarkan tujuh cara pemanfaatan remitan oleh keluarga migran.

Tabel 1. Tabel Pemanfaatan Remitan di Rumah Tangga Migran, Desa Pusakajaya Tahun 2011

\begin{tabular}{clcc}
\hline Kode & Cara Pemanfaatan Remitan & $\begin{array}{c}\text { Jumlah } \\
\text { Persentase } \\
(\%)\end{array}$ \\
\hline 1 & Konsumsi & 4 & 12,1 \\
4 & Konsumsi, produksi, investasi & 4 & 12,1 \\
& pendidikan, investasi ekonomi & & \\
\multirow{2}{*}{6} & Konsumsi, produksi, investasi & 2 & 6,1 \\
9 & Konsumsi, investasi pendidikan & 9 & 27,3 \\
10 & Konsumsi, investasi pendidikan, & 11 & 33,3 \\
& investasi ekonomi & & \\
13 & Konsumsi, investasi ekonomi & 2 & 6,1 \\
24 & Investasi pendidikan & 1 & 3,0 \\
& Total & 33 & 100,0 \\
\hline
\end{tabular}

\section{Tingkat Remitan Berdasarkan Karakteristik Responden}

Responden yang berangkat menjadi TKW ketika berumur $\mathrm{x} \leq 21$ tahun, mengirimkan remitan dengan tingkat yang rendah (0-25\%) sebanyak 57,1\% responden. Responden yang berumur $\mathrm{x}>21$ tahun ketika berangkat menjadi TKW, mengirimkan remitan dengan tingkat yang tinggi (51-75\%) dari upah yang mereka terima.

TKW yang menikah mengirimkan remitan lebih banyak dari pada TKW yang belum menikah atau pun janda. Walaupun demikian, jumlah yang mereka kirimkan bervariasi. TKW yang berstatus menikah mengirimkan remitan rendah (0-2\%) sebanyak 71,4\%, TKW yang mengirimkan remitan sedang (26-50\%) sebanyak 50,0\%, dan TKW yang mengirimkan remitan tinggi $(51-75 \%)$ sebanyak $70,0 \%$. Hal ini menunjukkan keterikatan wanita yang sudah menikah dengan keluarganya di daerah asal, dilihat dari remitan yang ia kirimkan ke daerah asal Desa Pusakajaya.

Responden yang memiliki tingkat pendidikan rendah (tidak tamat SD), sebanyak 14,3\% mengirimkan remitan rendah dan sebanyak 20,0\% mengirimkan remitan tinggi. Responden yang memiliki tingkat pendidikan sedang (tamat SD) lebih banyak mengirimkan remitannya ke daerah asal dengan jumlah yang bervariasi. Sebanyak $57,1 \%$ responden mengirimkan remitan dengan jumlah rendah, kemudian sebanyak $66,7 \%$ responden mengirimkan remitan dengan jumlah sedang, dan sebanyak 45,0\% responden mengirimkan remitan dengan jumlah yang tinggi. Responden yang memiliki tingkat pendidikan tinggi (tamat SMP dan tamat SMA), sebanyak 28,6\% mengirimkan remitan dengan jumlah rendah, sebanyak $33,3 \%$ mengirimkan remitan dengan jumlah sedang, dan sebanyak $35,0 \%$ responden mengirimkan remitan dengan jumlah yang tinggi.

\section{Tingkat Remitan Berdasarkan Lama Waktu dan Negara Tujuan}

Responden yang mengirim remitan tinggi (51-75\%), sebanyak 15 orang responden $(60,0 \%)$ yang bekerja di Timur Tengah, sebanyak 3 orang responden $(60,0 \%)$ yang bekerja di AsiaTimur, dan sebanyak 2 orang responden (66,7\%) yang pernah bekerja di Timur Tengah dan Asia Pasifik. Dapat dilihat bahwa responden yang mengirim remitan tinggi $(50-75 \%)$, sejumlah 20 orang $(60,6 \%)$ dari total responden 33 orang memang memiliki motivasi yang tinggi untuk bekerja membantu keluarga di daerah asal, karena kebanyakan upah hasil kerja migran di sana dikirimkan ke daerah asal untuk membantu biaya pendidikan anak dan kehidupan sehari-hari rumah tangga. Walaupun jika dilihat dari tingkat upah yang diterima migran, tingkat upah bekerja di Negara Timur Tengah lebih rendah dibanding tingkat upah bekerja di Negara Asia Timur, namun hal ini tidak membuktikan bahwa migran dengan upah yang tinggi akan mengirim remitan lebih besar ke daerah asal. Hal ini juga berarti bahwa semakin pengalaman bernegara, yaitu pernah bekerja di negara Timur Tengah dan Asia Timur, maka semakin tinggi tingkat remitan yang dikirimkan ke daerah asal. Hal lain yang berpengaruh pada tinggi rendahnya remitan yang dikirimkan ke daerah asal, yaitu rasa kecewa migran mengirimkan remitan ke daerah asal yang tidak dimanfaatkan sebaik-baiknya oleh keluarga di daerah asal, sehingga ia lebih memilih untuk menyimpannya dahulu sebelum dibawanya pulang ke Indonesia.

Selain itu, tingkat remitan juga dipengaruhi oleh lamanya bermigrasi. Hasil penelitian Murdiyanto (2001) menjelaskan bahwa remitan ditentukan oleh lamanya bermigrasi. Semakin lama bermigrasi maka semakin besar tingkat remitan yang migran sumbangkan pada rumah tangga di desa. Banyaknya responden yang bekerja ke luar negeri selama kurang dari sama dengan lima tahun $(\mathrm{x} \leq 5)$ sebanyak 19 orang $(57,6 \%)$, dan jumlah migran yang bekerja selama lebih dari lima tahun ( $>$ > 5) sebanyak 14 orang $(42,4 \%)$. Jumlah migran yang mengirim remitan $51-75 \%$ (tinggi) gaji sebanyak 20 orang $(60,6 \%)$, migran yang mengirim 26-50\% (sedang) gaji sebanyak 6 orang $(18,2 \%)$, dan migran yang mengirim $0-25 \%$ (rendah) gaji sebanyak 7 orang $(21,2 \%)$.

Migran yang telah bekerja selama kurang dari sama dengan lima tahun $(\mathrm{x} \leq 5)$, kemudian mengirimkan remitan dengan jumlah yang tinggi (51-75\%), sebanyak 13 orang $(68,4 \%)$, hal ini disebabkan pada tahun-tahun awal bekerja, upah/remitan yang diterima migran lebih banyak dikirimkan pada keluarga di daerah asal untuk memenuhi kebutuhan rumah tangganya, biaya pen-didikan, dan membayar hutang. Kemudian migran yang telah bekerja selama lebih dari lima tahun $(x>5)$, kemudian mengirimkan remitan dengan jumlah yang tinggi (51-75\%), sebanyak 7 orang $(50 \%)$. Dapat dilihat banyaknya migran 
yang mengirimkan remitan dalam jumlah tinggi sebanyak $60,6 \%$ dari total 33 responden, disebabkan keterikatan migran pada keluarga di daerah asal dan remitan merupakan sumbangan pendapatan yang sangat berarti bagi rumah tangga migran di Desa Pusakajaya. Bagi migran yang bekerja lebih dari lima tahun $(\mathrm{x}>5)$ cenderung lebih memilih untuk menyimpan hasil upahnya sendiri kemudian dibawa pulang untuk investasi.

\section{KESIMPULAN}

Faktor penyebab perempuan Desa Pusakajaya melakukan migrasi internasional tenaga kerja yang dilihat dari fator pendorong dari daerah asal Desa Pusakajaya dan faktor penarik dari daerah tujuan dipengaruhi oleh ketersediaan lapangan pekerjaan di daerah tujuan dengan upah yang tinggi dan semakin sempitnya lahan pertanian di daerah asal serta ketidaktersediaan lapangan pekerjaan di daerah asal menjadi faktor penyebab utama bagi perempuan Desa Pusakajaya untuk bekerja ke luar negeri.

Pemanfaatan remitan di Desa Pusakajaya dialokasikan dalam pemenuhan kebutuhan konsumsi, investasi pendidikan, investasi ekonomi, dan produksi, sedangkan untuk alokasi pemanfaatan remitan dalam bentuk investasi sosial (sumbangan untuk pembangunan desa) tidak ditemukan. Pemanfaatan remitan oleh keluarga migran di Desa Pusakajaya terfokus pada pemenuhan kebutuhan konsumsi dan investasi pendidikan.

\section{IMPLIKASI}

Mengingat peranan migrasi internasional yang besar terhadap perekonomian rumah tangga di Desa Pusakajaya, maka beberapa implikasi yang dianjurkan antara lain:

1. bagi pemerintah daerah dan pemerintah pusat, perlu terus mengupayakan peningkatan perlindungan dan pemberdayaan bagi TKW yang melakukan migrasi internasional tenaga kerja karena pentingnya remitan yang didapat dengan bekerja sebagai TKW sebagai strategi nafkah yang dilakukan perempuan desa dalam upaya meningkatkan perekonomian keluarga;

2. bagi pemerintah desa perlu melakukan pemberdayaan bagi perempuan yang akan berangkat menjadi TKW maupun mantan TKW agar memiliki kemampuan lebih baik dalam memanfaatkan pengalamannya menjadi TKW dan mengelola remitan/hasil yang didapat selama bekerja menjadi TKW, sehingga dapat berperan secara lebih nyata dalam proses pemberdayaan diri dan proses pembangunan di perdesaan terutama dalam usaha menciptakan lapangan pekerjaan di desa;

3. bagi penelitian sejenis di masa yang akan datang diharapkan mengarahkan penelitiannya lebih mendalam terhadap dampak adanya remitan, baik secara ekonomi maupun sosial.

\section{DAFTAR PUSTAKA}

[BNP2TKI] Badan Nasional Penempatan dan Perlindungan Tenaga Kerja Indonesia. 2010. [Internet]. [Dikutip 15 September 2010]. Dapat diunduh dari: http://www.bnp2tki.go.id/statistikmainmenu-86/data-penempatan-mainmenu-87/90penempatan-tenaga-kerja-indonesia-berdasarkanjenis-kelamin-tahun-1994-2006.html

Buchori C, Amalia M. 2006. Migrasi, remitansi dan pekerja migran perempuan. [Internet]. [Dikutip 27 Februari 2011]. Dapat diunduh dari: www.migrationinformation.org.

Dharmawan A. 2006. Sistem penghidupan dan nafkah perdesaan pandangan sosiologi nafkah (livelihood sociology) mahzab barat dan mahzab Bogor [ID]. Sodality: Jurnal Transdisiplin Sosiologi, Komunikasi, dan Ekologi Manusia. Vol. 01 (02).

Djuriah. 2000. Analisis keberhasilan program pengiriman TKW Indonesia ke luar negeri: kasus TKW ke Arab Saudi di Desa Sawah, Kecamatan Sukaraja, Kabupaten Sukabumi, Provinsi Jawa Barat. [Skripsi]. Bogor [ID]: Institut Pertanian Bogor.

Effendi TN. 2004. Mobilitas pekerja, remitan dan peluang berusaha di perdesaan. Dalam: Jurnal Ilmu Sosial dan Ilmu Politik. Vol. 8 (2): 218-222.[Internet]. [Dikutip 5 Februari 2010]. Dapat diunduh dari: ilib.ugm.ac.id/jurnal/detail.php?dataId=5637

Elizabeth R. 2007. Remitans bekerja dari luar negeri dan diversifikasi usaha rumah tangga di pedesaan: survai empat desa di Kabupaten Indramayu dan Kabupaten Pontianak. [Tesis]. Bogor [ID]: Institut Pertanian Bogor.

Hugo GJ. 1981. Population mobility in West Java. Yogyakarta [ID]: Gajah Mada University Press.

[IOM] International Organization for Migration Indonesia. 2010. Fact sheet, migration and development, remittances and Indonesian. [Internet]. [Dikutip 27 Februari 2011]. Dapat diunduh dari: http://www.iom.or.id/project/eng/ updates/MD\%20Remittances\%20and\%20Indonesi a\%20Fact\%20Sheet\%202010_eng(lo).pdf.

Jellinek L. 1986. Bab 5 sistem pondok dan migrasi sirkuler. Kuntjoro-Jakti D, editor. Kemiskinan di Indonesia. Jakarta [ID]: Yayasan Obor Indonesia.

Kustini. 2002. Perceraian dikalangan buruh migran perempuan: Studi kasus Desa Kadapura, Kecamatan Cibodas, Kabupaten Sukabumi, Provinsi Jawa Barat. [Tesis]. Bogor [ID]: Institut Pertanian Bogor.

Lee E. 1984. Suatu teori migrasi. (Alih bahasa dari bahasa Inggris oleh Hans Daeng). Yogyakarta [ID]: Pusat Penelitian Kependudukan UGM.

Mantra IB. 1994. Mobilitas sirkuler dan pembangunan daerah asal. Warta Demografi. No. 3. 
Mukbar D. 2009. Perdesaan, migrasi, dan perubahan penghidupan. [Internet]. [Dikutip 11 Februari 2011]. Dapat diunduh dari: http://akatiga.go.id/ Tabel/tenaga\%20kerja/tenagakerja4.html.

Murdiyanto E. 2001. Remitan migran sirkuler dan gejala perubahan struktur sosial di perdesaan Jawa. [Tesis]. Bogor [ID]: Institut Pertanian Bogor.

Pardede, IA. 2008. Pengaruh migrasi internasional terhadap daerah asal. Studi kasus TKI di Desa Kertamukti, Kec Haur Wangi, Kab Cianjur, Provinsi Jawa Barat. [Skripsi]. Bogor [ID]: Institut Pertanian Bogor.

Potensi Desa Pusakajaya. 2010. Daftar isian data profil desa dan kelurahan. Subang [ID]: Pemerintah Desa Pusakajaya Kecamatan Pusakajaya Kabupaten Subang Jawa Barat.

Raharto A (Editor). 1999. Migrasi dan pembangunan di Kawasan Timur Indonesia: Isu Ketenagakerjaan. Jakarta [ID]: Kerjasama Pusat Penelitian Kependudukan dan LIPI dengan The Australian National University dan The Australian Agency for International Development.

Roganda. 2004. Mobilitas dan status sosial buruh migran perempuan yang pernah bekerja di luar negeri. Studi kasus Desa Kutawangi, Kec Rawamerta, Kab Karawang, Provinsi Jawa Barat. [Skripsi]. Bogor [ID]: Institut Pertanian Bogor.

Salama NL. 2004. Tingkat remitan tenaga kerja wanita dan perkembangan kesejahteraan keluarga. Kasus di Desa Jambenenggang, Kec Kebunpedes, Kab Sukabumi, Provinsi Jawa Barat. [Skripsi]. Bogor [ID]: Institut Pertanian Bogor.

Scoones I. 1998. Sustainable rural livelihoods a framework for analysis, IDS Working Paper 72, Brighton: IDS.

Singarimbun M. 1989. Bab 1 metode dan proses penelitian. Singarimbun M, Effendi S, editor. Metode penelitian survai. Edisi Ke-19. Jakarta [ID]: LP3ES.

Toersilaningsih R. 2010. Mobilitas nonpermanen pekerja di Indonesia sebuah alternative dalam mengatasi kemiskinan. Warta Demografi. 40 (2).

Wahyuni ES, Muljono P. 2009. Bahan kuliah metode penelitian sosial. Bogor [ID]: Departemen Sains Komunikasi dan Pengembangan Masyarakat, Fakultas Ekologi Manusia, Institut Pertanian Bogor.

Warsito R. 2010. Tenaga Kerja Indonesia (TKI) peran dan pengaruhnya terhadap ekonomi rakyat di wilayah pedesaan di Propinsi Jawa Tengah. [Laporan Akhir]. Salatiga [ID]: Fakultas Pertanian, Universitas Kristen Satya Wacana.
Wulan TR. 2007. Pengetahuan dan kekuasaan: Penguatan remitan sosial sebagai strategi pemberdayaan buruh migran perempuan Indonesia. Warta Demografi. 37 (2).

2010. Pengetahuan dan kekuasaan: Penguatan remitan sosial sebagai strategi pemberdayaan buruh migran perempuan Indonesia. [Disertasi]. Bogor [ID]: Institut Pertanian Bogor.

Zid M. 2010. Belajar dari Panyingkiran dan Ciherang: Antara resiko dan manfaat migran internasional perempuan dari pedesaan. Warta Demografi. 40 (2).

Lampiran

PETA DESA PUSAKAJAYA

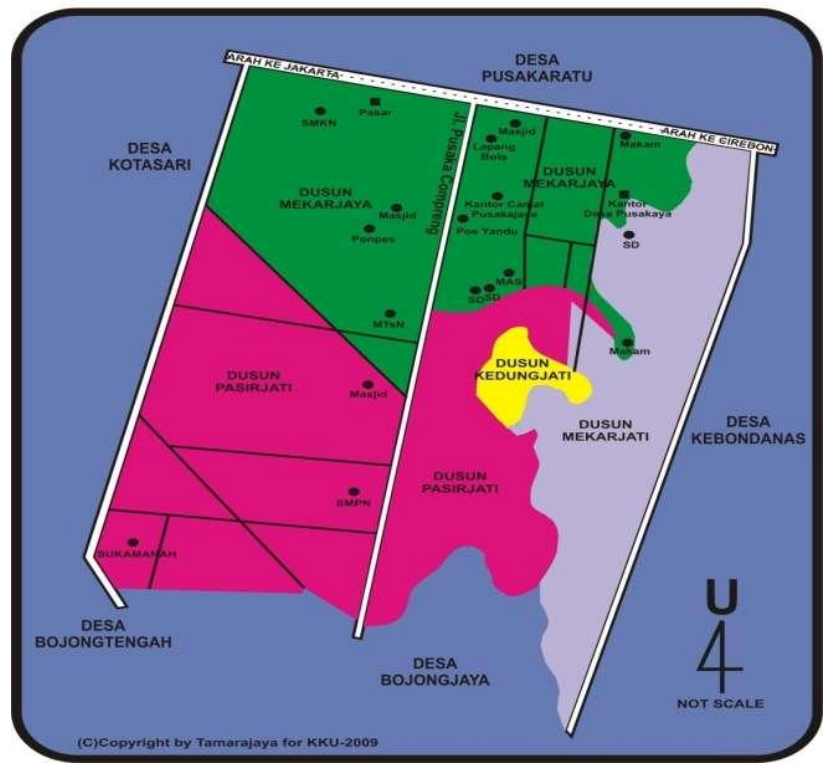

